\title{
Brazilian nursing in pandemic times and the bicentennial of Florence Nightingale
}

\author{
A enfermagem brasileira em tempos de pandemia e o bicentenário de Florence Nightingale \\ La enfermería brasileña en tiempos de pandemia y el bicentenario de Florence Nightingale
}

Beatriz Maria dos Santos Santiago Ribeiro'

ORCID: 0000-0001-5211-5422

Fabio Scorsolini-Comin'

ORCID: 0000-0001-6281-3371

Sérgio Valverde Marques dos Santos"

ORCID: 0000-0001-9412-9515

Rita de Cassia de Marchi Barcellos Dalri ORCID: 0000-0002-6575-5426

'Universidade de São Paulo. Ribeirão Preto, São Paulo, Brazil. "Universidade do Estado de Minas Gerais. Passos, Minas Gerais, Brazil.

How to cite this article: Ribeiro BMSS, Scorsolini-Comin F, Santos SVM Dalri RCMB. Brazilian nursing in pandemic times and the bicentennial of Florence Nightingale. Rev Bras Enferm. 2022;75(Suppl 1):e20210081. https://doi.org/10.1590/0034-7167-2021-0081

\section{Corresponding author:}

Beatriz Maria dos Santos Santiago Ribeiro E-mail: beatrizsantiago1994@hotmail.com

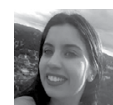

EDITOR IN CHIEF: Dulce Barbosa ASSOCIATE EDITOR: Maria Itayra Padilha

Submission: $05-27-2020$

Approval: 04-18-202

\section{ABSTRACT}

Objective: To reflect on the role of Brazilian nursing during the COVID-19 pandemic, considering as a historical landmark the bicentenary of the birth of Florence Nightingale, a precursor of modern nursing, celebrated in 2020. Method:Theoretical-reflective study, based on Florence Nightingale's environmental theory through a literature review, carried out in international and national virtual news from different sources and added to the authors' experiences related to the pandemic. Results: It was possible to identify the weaknesses experienced by nurse practitioners as to contagion by COVID-19, the routine of exposure to risks, the lack of adequate protection in many scenarios, the high rates of illness, and also deaths that occurred in this profession. Final considerations: Florence Nightingale's Environmental Theory describes the importance of the adequacy of the work environment. It also emphasizes the value of this professional for contemporary nursing and the redefinition of this professional category during the COVID-19 pandemic.

Descriptors: Coronavirus Infections; Disease Prevention; Nurse Practitioners; Nursing Theory; Health Services.

\section{RESUMO}

Objetivo: Refletir sobre a atuação da enfermagem brasileira durante a pandemia de COVID-19, tendo como marco histórico o bicentenário de nascimento de Florence Nightingale, precursora da enfermagem moderna, comemorado em 2020. Método: Estudo teóricoreflexivo, fundamentado na teoria ambientalista de Florence Nightingale, por meio de revisão de literatura realizada em noticiários virtuais, internacionais e nacionais, de diferentes fontes. Além disso, dos autores foram acrescidas as experiências relacionadas à pandemia. Resultados: Possibilitou identificar as fragilidades experimentadas pelos profissionais de enfermagem quanto ao contágio pela COVID-19, da rotina de exposição aos riscos, da ausência de proteção adequada em muitos cenários, das elevadas taxas de adoecimento e também de óbitos ocorridos nessa profissão. Considerações finais: A Teoria Ambientalista de Florence Nightingale descreve a importância da adequação do ambiente laboral. Assim como, enfatiza o valor da profissional para a enfermagem contemporânea e também para a ressignificação dessa categoria profissional durante a pandemia da COVID-19. Descritores: Infecções por Coronavírus; Prevenção de Doenças; Profissionais de Enfermagem; Teoria de Enfermagem; Serviços de Saúde.

\section{RESUMEN}

Objetivo: Reflejar sobre la actuación de la enfermería brasileña durante la pandemia de COVID-19, teniendo como marco histórico el bicentenario del nacimiento de Florence Nightingale, precursora de la enfermería moderna, conmemorado en 2020. Método: Estudio teórico-reflexivo, fundamentado en la teoría ambientalista de Florence Nightingale por medio de una revisión de la literatura, realizada en noticieros virtuales nacionales e internacionales de diferentes fuentes y sumado a las experiencias de los autores relacionadas a la pandemia. Resultados: Posibilitó identificar las fragilidades experimentadas por los profesionales de la enfermería en cuanto al contagio por COVID-19, de la rutina de exposición a los riesgos, de la ausencia de protección adecuada en muchos escenarios, de las elevadas tasas de contagio y también de muertes ocurridas en esa profesión. Consideraciones finales: La Teoría Ambientalista de Florence Nightingale describe la importancia de la adecuación del ambiente laboral. Se enfatiza también el valor de esta profesional para la enfermería contemporánea y para la resignificación de esa categoría profesional durante la pandemia de COVID-19. Descriptores: Infecciones por Coronavirus; Prevención de Enfermedades; Enfermeras Practicantes; Teoría de Enfermería; Servicios de Salud. 


\section{INTRODUCTION}

On March 11, 2020, the World Health Organization (WHO) declared the new coronavirus and COVID-19 pandemic since the cases had already spread to several countries on different continents. In early 2021, nine months after this outbreak, Brazil had already surpassed 200,000 deaths due to COVID-19 and its complications. The spread of the new coronavirus causing COVID-19 disease has spread throughout the world ${ }^{(1)}$. It is a fact that nurse practitioners felt the increase in care demand in health institutions; they are considered frontline workers in the fight against the pandemic, having direct contact with suspected and confirmed cases of the disease.

The work performed by the nursing teams is already considered exhausting due to the conditions in which they perform their activities and the occupational risks to which they are exposed (2). Faced with this pandemic, physical and mental exhaustion, insecurity, and fear of contracting the disease can further compromise the health of these practitioners.

Nurse practitioners are highly susceptible to contagion. In many countries, including Brazil, many of these workers were removed from their work activities for having acquired the disease, and many died due to COVID-19. The Federal Nursing Council and the International Council of Nurses state in 2020 that Brazil was considered the country with the highest number of deaths in the world among nurse practitioners who were working on the front line against COVID. 19. Brazil has surpassed the number of deaths of nurse practitioners compared to the United States and the United Kingdom ${ }^{(3)}$.

The nursing teams that worked on the front line with care for patients with cases of COVID-19 showed symptoms of physical and mental exhaustion, difficulties in decision making, and anxiety due to the anguish of losing patients and co-workers. Besides, they were afraid of the risk of contamination and the likelihood of transmitting the virus to their families.

Given the above, it is clear the importance of using Florence Nightingale's Environmental Theory today, a theory that focuses on five fundamental pillars to help protect against diseases: clean air, sanitation, cleaning, pure water, and light ${ }^{(4)}$. These pillars are extremely important given infectious and contagious diseases, such as COVID-19, which can be avoided through simple measures based on the observation and maintenance of these pillars.

The historical and sanitary connection of Florence's theory was presented during the Crimean war, considering the care of personal and environmental hygiene in the period that extended from 1853 to 1856 . Florence managed to reduce the mortality of soldiers by $72 \%$, which made her stand out in history as an administrator and sanitarist ${ }^{(4-5)}$. Since her legacy as a precursor of nursing, knowledge focused on routine care, the environment, and handwashing has become efficient and based on science.

Nurse Florence Nightingale was also a British statistician, politician, social reformer, and writer. Florence Nightingale's Environmental Theory provides subsidies for health workers to exercise their activities more safely. It is important to emphasize that she considered maintaining a healthy environment relevant. That is, she acted preventively in the face of occupational risks, facts that are relevant during a pandemic ${ }^{(5)}$. Although 167 years have passed since the beginning of the use of the Environmental Theory, it is present and necessary at a pandemic time, and the importance of using its teachings is notorious, given the high probability of contagion among health professionals, a fact that can suddenly change their status from caregivers to patients.

Given the above, one can see the relevance of the role of the nursing team during a pandemic, which in the case of the current one, is caused by a virus. Thus, the choice of this theme justifies the elaboration of this theoretical-reflective essay, since preventive measures are essential to avoid illness among nurse practitioners and other health workers and collaborate with the control of the spread of this virus. Allied to this, Florence Nightingale's Environmental Theory provides historical insights into her contribution to contemporary nursing, especially in 2020, when the bicentenary of her birth was celebrated.

\section{OBJECTIVE}

To reflect on the role of Brazilian nursing during the COVID-19 pandemic, considering as a historical landmark the bicentenary of the birth of Florence Nightingale, a precursor of modern nursing, in 2020.

\section{METHODS}

This is a theoretical-reflective essay, supported by the Nursing Theorist in question, which can help understand nursing activities and their complexity ${ }^{(6)}$. Thus, the theoretical focus used in this study was Florence Nightingale's Environmental Theory, which aimed to organize the care process, ensuring the health of health professionals and especially nurse practitioners.

This theoretical-reflective essay was developed from March 2020 to January 2021, had systematic procedures for the search for studies and reflections, considering a pandemic scenario still ongoing, as information on this theme is still in production and broadcast, especially considering the start of immunization in countries like the United States, the United Kingdom, and Israel in December 2020 and the expectation of the start of vaccination in Brazil in the first half of 2021.

Searches were carried out in international and national virtual articles from reliable sources, considered as the primary news and from official websites such as World Health Organization, Ministry of Health and Federal Nursing Council (COFEN), adding the authors' experiences as to the pandemic and Florence Nightingale's Environmental Theory.

Searches were also performed for scientific articles in the databases of the Virtual Health Library (BVS), US National Library of Medicine (PubMed), Scopus, Web of Science, and Google Scholar. To carry out these searches, controlled descriptors were used and identified in the Health Sciences Descriptors (DECs), Medical Subject Headings (MESH), and CINAHL Headings: "teoria de enfermagem" (nursing theory), "profissionais de enfermagem" ("nurse practitioners"), "serviços de saúde" ("health services") e "coronavírus" ("coronavirus"), in addition to the keywords: "COVID-19" ("2019-ncov").

\section{RESULTS AND DISCUSSION}

Florence Nightingale described her theory in four concepts: person, nursing, environment, and health, all focused on the care function and simple procedures such as hand washing and 
organization of the work environment. Nursing theories represent the combination of considerations and propositions that solidly clarify phenomena of interest to nursing, as these professionals need to develop their activities in an organized physical environment, have fair and adequate workloads, and the number of professionals must be correctly contingent, in order to avoid the pressure on their attributions ${ }^{(7)}$, since it presents guidelines that aim at the organization of the care process, guaranteeing the health of the professionals.

During the pandemic, through information linked by the Federal Nursing Council (COFEN) and also by Regional Nursing Councils (CORENs) $)^{(8)}$, it was possible to identify the need for guidance and planning of actions that can contribute to reducing physical and psychological harm among nurse practitioners, such as the prevention of COVID-19 and other psychosomatic illnesses related to mental health, due to psychopathological symptoms such as stress, burnout syndrome, depression and anxiety related, for example, to the fear of contaminating family members and also the fear of death.

The measures recommended by Florence represent the initial impulse for the formation of a scientific profession based on safe care. Prophylaxis methods for numerous pathogens and diseases represent much of the historical and contemporary nursing practice. Florence cooperated with evidence-based studies, constructing indicators that consented to analyze risk/protection factors in the face of epidemics/pandemics and contributed to primary health care. The coordination of knowledge combined with practice was and has been fundamental for restructuring care, from Florence's time to the current pandemic condition of COVID-19. Two analytical categories produced from the revised literature were elaborated and are presented and discussed below to discuss these elements.

\section{Weaknesses of nurse practitioners in coping with the COVID-19 pandemic based on Florence Nightingale's Environmental Theory}

In facing the COVID-19 pandemic, it was possible to identify many weaknesses related to health professionals, especially the nursing ones. According to an epidemiological study carried out in $2020^{(9)}$, in China, Italy, and the United States, there was great contamination of these workers, as relevant information was reported late, such as the possibility of contamination by the disease through urine, feces, or saliva. These fluids, until then, were handled by nurse practitioners without adequate protection. Therefore, it was found a high rate of Chinese nurse practitioners infected and affected by COVID-19, noting that many of them died $^{(9)}$. It is emphasized that even with disseminating information related to the forms of virus transmission, many health professionals still became contaminated in Brazil, and some died ${ }^{(8)}$.

Based on Florence's Environmental Theory, it is clear that it is not enough to have theoretical knowledge about the real problem. However, it is also important to concerned with the environment, the development of appropriate techniques ${ }^{(7)}$, and equipment availability. Personal Protective (PPE) and Collective Protective Equipment (CPE), which can bring positive results ${ }^{(3)}$. As Florence's theory is focused on working conditions, considering the environment experienced during the care of individuals $s^{(5)}$, it is relevant to the various fields of current practice facing an infectious disease such as COVID-19. Theoretical knowledge and its usefulness in the current context are important, helping health professionals to deal with the ongoing pandemic.

Since the primary cases of COVID-19, a clinical management protocol has been instituted for physicians and nurse practitioners. The protocol decides, among others, that physicians and nurse practitioners who take care of infected clients should dedicate themselves only to them and avoid circulation by other extensions of the institution they work ${ }^{(9)}$. However, nurse practitioners consider that the pandemic situation, even though there are protocols with precise guidelines on how to proceed, is quite chaotic, given that new information about COVID-19 emerges at every moment ${ }^{(9-10)}$.

Nursing experienced moments of uncertainty and doubts, such as whether there would be beds for all patients who needed hospitalization, whether there would be adequate and sufficient supplies such as PPE and whether the number of practitioners would be sufficient to meet the demands in outpatient clinics, Emergency Care Units (UPA), and in hospitals. This concern, which began in Brazil in the first half of 2020, was updated in the second half of the year due to the second wave of infection, which was also ongoing in the first half of 2021. There was great concern by COFEN authorities as to nurse practitioners being in the front line in the fight against the pandemic. COFEN advised that all state units inspect the regional health areas to investigate these professionals' work situations, the provision of PPE, supplies, and the quantity and training of teams ${ }^{(8)}$.

When considering the experiences and discoveries of other countries on how to deal with the pandemic, it would be important to have different plans concerning pandemic management in the Brazilian context ${ }^{(9)}$. It is the nurse practitioner who is at the patient's side most of the time, providing the necessary care and managing the entire flow of care, thus exposing themselves to different contagion levels. As to the assumptions of Florence's Environmental Theory, it is noteworthy that the careless work environment generates contamination and, consequently, illness among professionals ${ }^{(7)}$.

In the pandemic context, many nurse practitioners were infected worldwide ${ }^{(9)}$. In Brazil, it was no different. Along with the work, the psychological pressure due to the weaknesses in dealing with this pandemic came, which made the hands that care also infected patients. Of the infected nurse practitioners, some became ill and took time away from work, becoming isolated in their homes, others were admitted to wards and Intensive Care Units (ICU), and others died ${ }^{(8-10)}$. In this sense, the precursor of Nursing theory shows similarities in moments experienced during their professional career; as a result of the advance of the Crimean war, she fell ill with her first episode of fever ${ }^{(7)}$.

It is noteworthy that the news reported that these practitioners were infected at work, possibly due to the lack of PPE, and had to leave, precisely at a critical moment, when they should treat the victims of COVID-19(8-10). From this perspective, nursing must be based on care for environmental hygiene, aiming to prevent or minimize disease transmission. It is noteworthy that Florence's findings are very relevant. At the time of a pandemic, they can add to the technological and technical-scientific development in advancing the development of health professionals' activities, especially the nursing ones ${ }^{(5-7)}$. 
Environmental control is the main concept in Nightingale's writings. External conditions and influences compromise the life and development of organisms; they can precede, eliminate, or contribute to health ${ }^{(7)}$. During the pandemic in Brazil, health professionals suffer from the scarcity, mainly of masks and the disorganization of work environments. The most affected are the nurse practitioners, as they are in the front line in relation to welcoming and nursing care. As a result, it did not take long for the first infected and sick nurse practitioners to appear ${ }^{(8)}$. Related to these assumptions, the principles of actions that should be implemented when performing nursing techniques properly with patients were compromised, given that health institutions were unprepared to face the pandemic ${ }^{(8-9)}$.

Florence's objective was to prioritize providing a motivating environment in which nurses could contribute to the development of their patients' health. She hoped that this would make a difference in the recovery of patients, and these are the precepts that support the Environmental Theory. Florence then went on to follow and give importance to components that determined factors related to the environmental issue, which need to be interrelated, they are physical, social, and psychological, and they should not be distinct and separate parts ${ }^{(4)}$. Florence's Environmental Theory promoted and introduced in nursing not only a vision of intervention aimed at the patient, but it expanded the performances for the environment, establishing services with the organization and cleaning of sectors, having the influence of the treatment environments for the patients through observation and supervision, which required organization and hierarchy ${ }^{(5-7)}$.

During the ongoing pandemic, even without becoming infected with the disease, nurse practitioners had to distance themselves from their families as a protective measure ${ }^{(8)}$. However, due to contamination and disease, anguish and suffering increased as they began to undergo treatment at home or in hospital, maintaining isolation ${ }^{(8-9)}$. The testimonies of these professionals and their families on social networks arouse attention, as they reveal that these professionals, at many times, found themselves immersed in feelings of impotence and uselessness in combating the pandemic. The cases of nurse practitioners who evolved to death ended up moving other co-workers, leaving them sensitive, fearful, and insecure to assist other patients with the disease ${ }^{(8-9)}$. Then, other problems of a psychological nature were identified. An example was a 34-year-old nurse practitioner who worked on the front line in combating COVID-19 in the ICU of a hospital in Lombardy (Italy), who committed suicide. According to family members, she lived under very strong stress, afraid of having infected other people, taking her own life ${ }^{(10)}$.

Therefore, the importance of reporting common situations experienced by nursing in combating the disease is highlighted because, in the desire to offer better care to patients and also take care of their own health, these professionals are requesting emergency actions from the authorities and their respective councils, to provide qualified nursing care without being at the risk of also becoming infected patients ${ }^{(8)}$. In mid-1855, after the Crimean war, Florence Nightingale went through a similar situation when she became ill. It is assumed that due to precarious working conditions, lack of physical and human resources and excessive work ${ }^{(7)}$.
Based on the foundations of the Environmental Theory, the importance of practitioners and Institutions being prepared to face outbreaks, epidemics, and pandemics is highlighted, aiming at better working conditions and safety for health workers, fewer leaves of absence, and, consequently, faster control of the situation caused by such events. The beginning of 2021 shows the advance in the fight against the virus globally with the discovery of vaccines.

\section{Contributions to the field of Nursing}

It is understood that during a pandemic, such as that of COVID-19, the role of the nursing team is essential, as they are practitioners who work in the so-called front line in dealing with these types of illnesses. Recovering Florence Nightingale's Environmental Theory during the pandemic leads us to reflect on the essence of care for patients, however, without forgetting the care for one's own health in the workplace.

It is assumed that this reflection can support the understanding of the challenges and possibilities of adequate care practices, which can be developed by the nursing staff during a pandemic, without these practitioners having consequences of contamination and disease problems. It is important that Florence's legacy can be revisited, especially when the bicentennial of her birth is celebrated, which led nursing to celebrate in 2020 the world year of this profession. This celebration leads us to think not only about how Florence's theory can be recovered and updated but how nursing knowledge has matured and developed as a result of the health and care needs triggered over time.

The current scenario of the pandemic, bringing several challenges to nursing work, must also be propositional in valuing this profession, with greater visibility and a better understanding of the science of care, initially disseminated by Florence. Dialogue with these aspects should promote greater respect for this category and, also, a social representation of nurses, supported by humanizing and scientific elements involving care.

\section{FINAL CONSIDERATIONS}

This theoretical-reflective essay recovered the teachings of the Nursing precursor, Florence Nightingale, drawing a parallel between the COVID-19 pandemic and the Environmental Theory. Such teachings highlighted the importance of prevention, protection, and health promotion for nurse practitioners and other health professionals regarding the risk factors to which they are constantly exposed.

It must be considered that Florence's assumptions are a landmark for the health area and, even after several years, they are current and relevant, not only concerning the maintenance of environmental hygiene, control of microorganisms, and assurance of safety in the treatment of patients but for the applicability in practical nursing care, as well as in the health team.

The present article helps produce knowledge about this theme and in the understanding of the exposed theory, stimulating its practical application in work environments. It also allows reflection on occupational risks and weaknesses experienced by nurse practitioners during the pandemic, highlighting the need for interventionist actions to maintain the physical and mental health of these workers. 


\section{REFERENCES}

1. Yuen KS, Ye ZW, Fung SY, Chan CP, Jin DY. SARS-CoV-2 and covid-19: The most important research questions. Cell Biosc. 2020;10:40. https:// doi.org/10.1186/s13578-020-00404-4

2. Ribeiro BMSS, Hirai VHG, Teston EF. A redução de perícias médicas baseado na gestão de absenteísmo, rotatividade e qualidade de vida no trabalho. Rev Gestao Saude. 2018;9(3):393-403. https://doi.org/10.26512/gs.v9i3.20291

3. Conselho Federal de Enfermagem (BR). Brasil é o país com mais mortes de enfermeiros por Covid-19 no mundo: conselho federal de enfermagem e conselho internacional de enfermeiros falam que números estão acima de outros países com alta taxa de transmissão do vírus, como Reino Unido e Estados Unidos [Internet]. Brasília, DF: 28 maio 2020[cited 2013 Apr 10]. Available from: http://www.cofen.gov. br/brasil-e-o-pais-com-mais-mortes-de-enfermeiros-por-covid-19-no-mundo-dizem-entidades_80181.html\#: :text=28\%2F05\%2F2020,Brasil\%20\%C3\%A9\%20o\%20pa\%C3\%ADs\%20com\%20mais\%20mortes\%20de\%20enfermeiros\%20por,Reino\%20Unido\%20e\%20 Estados\%20Unidos

4. Lee G, Clark AM, Thompson DR. Florence Nightingale: never more relevant than today [Editorial]. J Adv Nurs. 2013;69(2):245-6. https://doi. org/10.1111/jan.12021.

5. Bezerra CMB, Silva BCO, Silva RAR, Martino MMF, Monteiro Al, Enders BC. Análise descritiva da teoria ambientalista de enfermagem. Enferm Foco. 2018;9(2):79-83. https://doi.org/10.21675/2357-707X.2018.v9.n2.1105

6. Ribeiro BMSS, Martins JT, Silva VA, Teston EF, da-Silva AC, Martins EAP. Enfermagem do trabalho na construção civil: contribuições à luz da teoria da adaptação de Roy. Rev Bras Med Trab. 2019;17(2):260-7. https://doi.org/10.5327/Z1679443520190364

7. Fernandes V. Análise da invexibilidade de Florence Nightingale. Conscientia [Internet]. 2007[cited 2020 Mar 30];11(4):271-9. Available from: http://ceaec.org/index.php/conscientia/article/viewFile/161/163

8. Emanuel JE, Persad G, Upshur R, Thome B, Parker M, Glickman A, et. al. Fair allocation of scarce medical resources in the time of Covid-19. New Engl J Med. 2020;382(21):2049-55. https://doi.org/10.1056/NEJMsb2005114

9. World Health Organization (WHO). Coronavirus disease (COVID-19) pandemic [Internet]. Geneva: WHO; 2019[cited 2020 Apr 9]. Available from: https://www.who.int/emergencies/diseases/novel-coronavirus-2019

10. Dias R. Enfermeira italiana se suicida depois de contrair coronavírus. Estado de Minas [Internet]. 2020 Mar 25[cited 2020 Apr 8]. Editoria Internacional. Available from: https://www.em.com.br/app/noticia/internacional/2020/03/25/interna_internacional,1132504/enfermeiraitaliana-se-suicida-depois-de-contrair-coronavirus.shtml 